\title{
Use of Complementary and Alternative Medicine (CAM) among Breast Cancer Patients in a Public Hospital in Padang, Indonesia
}

\author{
Dedy Almasdy ${ }^{1 *}$, Elsa Eptiyeni ${ }^{1}$, Daan Khamri ${ }^{2}$, Nina Kurniasih ${ }^{3}$ \\ 'School of Pharmaceutical Science, Andalas University, INDONESIA. \\ 2Dr. M. Djamil Hospital, Padang, INDONESIA. \\ ${ }^{3}$ Dr. Rasidin Hospital, Padang, INDONESIA.
}

\begin{abstract}
Objective: Number of CAM user among person suffer from cancer was high, especially breast cancer. The aim of this study was to investigate the use of CAM in breast cancer patients in a public hospital in Padang, Indonesia. Methods: This study was descriptive study with cross-sectional design done for three months for all patients suffering from breast cancer in oncology unit in a public hospital in Padang, Indonesia. Breast cancer patients who are unable to communicate well and/or are unwilling to take part in the study are excluded. Data were collected by structured interview for patients who used CAM and open interview for patients who not use CAM. Results: Among 85 participants, 8 of them (9.41\%) never use CAM, 22 of them (25.88\%) had used CAM for some period and 55 of them (64.71\%) had been using CAM. Herbal medicine was the most commonly used in CAM therapies, followed by supplement, spiritual healing, and Chinese medicine. The reason to use the CAM is their belief that the CAM has a positive impact to help them fight the cancer. Family and friends were the most common source of CAM information. Only $29.09 \%$ of participants
\end{abstract}

had discussed CAM that they want to use with health care providers. Conclusion: It is necessary for health care providers to give information to patients about safety and efficacy of CAM therapy.

Key words: Complementary and alternative medicine, Complementary and alternative therapy, Herbal therapy, Herbal medicine, Breast cancer, Hospital pharmacy, Indonesia.

Correspondence

Dr. Dedy Almasdy, Apt., M.Si., Ph.D (clin pharm), School of Pharmaceutical Science, Andalas University, Indonesia, Kampus Universitas Andalas, Limau Manis, Pauh, Kota Padang, Sumatera Barat 25163, INDONESIA.

Phone: +6275171181

Email: dedyalmasdy@phar.unand.ac.id

DOI: 10.5530/jyp.2018.2s.30

\section{INTRODUCTION}

Cancer is a disease characterized by uncontrolled cell growth, local tissue invasion and then metastasis. ${ }^{1}$ Cancer is responsible for 8.2 million deaths. That is the second leading cause of death after cardiovascular disease. About half of men and one-third of women have cancer during their lifetime, and today millions of people are living with cancer. Most common cancers are breast cancer, lung and bronchial cancers, prostate cancer, colon and rectal cancer, and bladder cancer. In United States, 231.840 new cases of invasive breast cancer and 60.290 cases of breast cancer 'in situ' are diagnosed among women. ${ }^{2}$ In Indonesia the prevalence of cancer in 2013 is $1.4 \%$ of the population or about 347,792 people, $0.5 \%$ of them suffer from breast cancer. Sumatera Barat (one of a province in Indonesia) was rank on $3^{\text {rd }}$ top position after Yogyakarta and East Kalimantan.

The main treatment for cancer is a combination of surgery, radiation, chemotherapy and biological therapy. ${ }^{1}$ Some of the patients also use CAM therapy, a treatment which uses products/procedures that are not considered as part of conventional treatment. ${ }^{2}$ The CAM therapy that commonly used by cancer patients is herbal medicines together with homeopathy, vitamins/minerals, spiritual therapy and relaxation..$^{4-9}$ Most of the patients who use CAM treatment usually because they are not satisfied with conventional treatment only. ${ }^{10}$

The CAM user population is widely spread in the world and continues to increase from year to year. More than one-third of cancer patients (35.9\%) worldwide were reported used some form of CAM medicine variations. ${ }^{11}$ In the United States, about 38\% of adults and $12 \%$ of children use some form of CAM. ${ }^{12}$ In South Korea $67 \%$ of breast cancer patients used CAM in treatment. ${ }^{13}$ In Malaysia the use of cam is also very popular. ${ }^{14-15}$ In Indonesia, CAM therapies are used more than $40 \%$ of the population and $70 \%$ of them was villagers. ${ }^{3}$ The Minister of Health Regulation state that CAM treatment was a continuous service effort as a promotive, preventive, curative and rehabilitative. ${ }^{16}$ This study is aimed to explore the CAM usage and the reasons of using CAM among breast cancer patients in a public hospital in Padang, Indonesia.

\section{METHODS}

This study was a descriptive study with the cross-sectional design done in three months for all patients suffering from breast cancer in oncology unit in a public hospital in Padang, Indonesia. The breast cancer patients who are unable to communicate well and/or are unwilling to take part in the study were excluded. Data were collected by structured interview for patients who use CAM and open interview for patients who not use CAM.

\section{RESULTS}

A total of 92 breast cancer patients were included in the study. Five of patients were unable to communicate well and two others were not willing to participate in the study, so total patients as respondents were 85. Using the CAM among the respondents is shown in Table 1 and 2.

This is an open access article distributed under the terms of the Creative Commons Attribution-NonCommercial-ShareAlike 4.0 License, which allows others to remix, tweak, and build upon the work non-commercially, as long as the author is credited and the new creations are licensed under the identical terms. 
Table 1: Using the CAM among the breast cancer patients.

\begin{tabular}{ccc}
\hline Practice & $\mathbf{n}$ & $\%$ \\
\hline Use the CAM & 55 & 65 \\
Use the CAM but now it has stopped & 22 & 26 \\
Never use the CAM & 8 & 9 \\
Total respondents & 85 & 100 \\
\hline
\end{tabular}

Table 2: Pattern of CAM usage on the patients who use the CAM $(n=55)$.

\begin{tabular}{|c|c|c|}
\hline Variables & $\mathbf{n}$ & $\%$ \\
\hline \multicolumn{3}{|l|}{ Reason to use the CAM } \\
\hline - Cheap and easy to use & 1 & 1.82 \\
\hline - No side effects & 6 & 10.91 \\
\hline - Patient's belief in the positive effects of CAM & 37 & 67.27 \\
\hline - Others & 11 & 20.00 \\
\hline \multicolumn{3}{|l|}{ Types of the CAM used } \\
\hline \multicolumn{3}{|l|}{ Biological-based therapy } \\
\hline - Herbal & 51 & 92.72 \\
\hline - Supplement & 9 & 16.36 \\
\hline - Jamu & 3 & 5.45 \\
\hline \multicolumn{3}{|l|}{ Mindbody-based therapy } \\
\hline - Praying & 2 & 3.64 \\
\hline - Meditation & 1 & 1,82 \\
\hline \multicolumn{3}{|l|}{ Medical-alternative therapy } \\
\hline - Acupressure & 1 & 1.82 \\
\hline - Chinese medicine & 2 & 3.64 \\
\hline - Cupping technique & 1 & 1.82 \\
\hline - Warsito's jacket & 1 & 1.82 \\
\hline - Acupuncture & - & - \\
\hline \multicolumn{3}{|l|}{ Body-manipulation therapy } \\
\hline - Massage & - & - \\
\hline \multicolumn{3}{|l|}{ Energy-based therapy } \\
\hline Information resources & 39 & 70.91 \\
\hline - Family and/or friends & 16 & 29.09 \\
\hline - $\quad \mathrm{TV}$, radio, newspaper, internet, book, etc. & 4 & 7.27 \\
\hline - Medical Doctor/Pharmacist & 3 & 5.45 \\
\hline $\begin{array}{l}\text { - Other health professional } \\
\text { - Others }\end{array}$ & 3 & 5.45 \\
\hline \multicolumn{3}{|l|}{ Consultation of CAM use to health professional } \\
\hline - No & 39 & 70.91 \\
\hline - Yes & 16 & 29.09 \\
\hline
\end{tabular}

\section{DISCUSSION}

The patients who have never used CAM, the main reason was that the efficacy and outcome of therapy were unclear. The result was similar with another study which reported there is no improvement on survival and on patient's quality of life. ${ }^{17-20}$ Meanwhile, Molassiotics reported, another reason why respondents choose not to use CAM was that they were satisfied with their conventional therapy and because they did not trust in CAM. $^{9}$

In patients who have use CAM, they have specific individual reasons. The main reason is that the patients' belief that CAM therapy would give benefit to support their health. Similar with the previous study reported that patients have an expectation CAM could improve their body's ability to fight on disease and improve quality of life..$^{8-10,21-22}$
Most of the respondents used biological-based therapies as an option in using the CAM, i.e. herbal medicine (92.72\%). Similar to this study, Molassiotics $^{9}$ and Gulluoglu ${ }^{23}$ reported that herbal remedies, treatment with tea, vitamins and minerals, spiritual therapy, homeopathy and relaxation techniques were most popular CAM therapy in cancer patients. Other study reported that herbal medicines and dietary supplements were widely used to overcome side effects of conventional cancer treatment and several studies have done to prove the efficacy of CAM as well. ${ }^{23}$ The CAM usage, especially herbal medicines, most likely influenced by the community tradition in using natural medicines. According to Algier, ${ }^{24}$ use of herbal medicines compared to other CAM therapies was influenced by cultures. Other factors were because of herbal remedies also popular, readily available, inexpensive in price and belief that natural product was safe for a body as well. This was supported by Teng ${ }^{25}$ which state that high prevalence of CAM usage in Chinese society was influenced by traditions, religious and belief, as well as money they spend for conventional treatments.

The patients also use the mind and body therapy, such as with praying and meditation. Praying was a form of meditation directed directly to God. ${ }^{26}$ Praying was a spiritual need and teaches how to overcome spiritual pressure. ${ }^{27}$ Praying was an individual behaviour that can also affect self-satisfaction and social support. ${ }^{28}$ Praying was often associated with one's faith, but Swisher ${ }^{22}$ states that there was no difference in the type of CAM therapy used with one's level of faith.

Meditation is a relaxation technique to calm the body and mind by focusing on an object, repeating words or mantras and regulating breathing techniques. This type of therapy indicates a change in the result of the biochemical compound including lowering blood pressure and lowering stress. ${ }^{26}$ In this study, meditation was not included as popular CAM choice for participants as only one of them used meditation.

The patients in this study also used Chinese medicine to treat their disease. It was reported that Chinese medicine derived from herbs worked synergistically with medical treatment and could decrease effects of toxicity, stress, and fatigue from cancer treatment itself. ${ }^{24}$

In addition, few respondents were using acupuncture and acupressure. According to the National Institutes of Health ${ }^{2}$ acupuncture was a treatment, procedure or techniques that involve the stimulation of the anatomical location of the skin by certain techniques and by penetrating the skin with a thin needle. In contrast to acupuncture, acupressure is a treatment technique by providing pressure using the thumb, finger or elbow at certain points on the muscles that can stimulate the ability of self to be healing naturally. Acupressure was believed to reduce muscle tension and facilitate the distribution of oxygen and nutrients to all parts of the body. Based on the study done by Bokmand and Flyger ${ }^{29}$ acupuncture can reduce sleep disorders and was a good and safe treatment for women with breast cancer. Acupuncture and acupressure were also effective in reducing nausea and vomiting due to cancer treatment. ${ }^{30}$

Source of information in using CAM usually was not just single information. Few studies reported different results where most patients get CAM information, especially herbal medicines, that information came from drug vendors themselves. ${ }^{9,17,24,31-32}$ In this study, most of the participants got information from family or friends (70.91\%) and from advertising through TV, radio, newspaper, internet, book, etc. (29.09\%). Only 5.45\% patients had consulted the CAM therapies that they used to health personnel. This is similar to others study where most of breast cancer patients do not seek advice from the medical practitioner about the CAM they want to use. . $^{13,25,33}$

Therefore, it is important for health personnel to ask about CAM was used by patients during cancer treatment and educate patients about the potential dangers of CAM if they used them as treatment primarily as treatment because the benefits of CAM use were unproven. ${ }^{22}$ 
Boon $^{34}$ also states how important medical staff knew about using of CAM in breast cancer patients because of lack of research that could expose safety, efficacy, and interaction of those treatment techniques with conventional treatment. Some experts believe that herbal medicines interact significantly with drugs so advice patients not to use herbal therapy during treatment. ${ }^{22}$ Some herbal medicines were hepatotoxic and therefore harmful when combined with some chemotherapy drugs. ${ }^{35}$ According to Swisher ${ }^{22}$ another important reason for consulting CAM use with medical staff was to clarify the reasons why patients use CAM. Medical staff should identify the quality of life of patients such as anxiety, depression, nausea and fatigue that often leads to patient dissatisfaction. Medical staff should also improve personal relationships to discuss other therapies that they use outside of conventional therapy.

\section{CONCLUSION}

Majority of breast cancer patients use CAM, especially biological-based therapies. The information resources are family and friends, while few of them have consulted their CAM to health personnel. It is recommended that health workers, especially clinical pharmacists, explore information about CAM use by patients and may provide information on appropriate CAM use. Further research is conducted on the efficacy, safety, side effects, and potential interactions of CAM therapies with medicaments received by patients from conventional medicine.

\section{ACKNOWLEDGEMENT}

We would like to acknowledge the research grant by Andalas University for founding this study.

\section{CONFLICT OF INTEREST}

The authors declare no conflict of interest.

\section{ABBREVIATIONS USED}

CAM: Complementary-Alternative Medicine

\section{REFERENCES}

1. DiPiro JT, Talbert RL, Yee GC, et al. Pharmacotherapy: A Pathophysiological Approach. New York: Mc Graw Hill Companies. 2008.

2. NIH. Cancer Alternative Therapies. US National Library of Medicine. 2015. https://www. nlm.nih.gov/medlineplus/ canceralternativetherapies.html. Accesed 31 Januari 2016

3. WHO. Legal Status of Traditional Medicine and Complementary/Alternative Medicine: A Worldwide Review. 2011.

4. Hye-Yeon H, Hyung-Woo K, Yong HS, et al. Anti-cancer effects of Kochia scoparia fruit in human breast cancer cells. Pharmacognosy Magazine. 2014;10(3):661-7.

5. Bahera B, Dash J, Pradhan D, Tripathy G, Pradhan R. Apoptosis and necrosis of human breast cancer cells by an aqueous extract of Euphorbia Hirta Leaves. J Young Pharm. 2016;8(3):186-93.

6. Siddiqui MJ, Min CS, Verma RK, Jamshed SO. Role of complementary and alternative medicine in geriatric care: A Mini Review. Pharmacognosy Magazine. 2014;8(16):81-7.

7. Prasad R, Lawania RD, Gupta MR. Role of herbs in the management of asthma. Pharmacognosy Magazine. 2009;3(6):247-58

8. Bishop F, Prescott P, Chan Y, et al. Prevalence of complementary medicine use in paediatric cancer: A systemic review. Pediatrics. 2010;125(4):768-76.

9. Molassiotics A, Ortega O, Pud D, et al. Use of complementary and alternative medicine in cancer patients: a Europian survey. Annals of Oncology. 2005; 16(4):655-63.

10. Ernst E. Patient Information: Complementary and Alternative Medicine Treatments (CAM) for cancer (Beyond the Basics). 2015. http://Uptodate.com/ Contents
I Complementary-and-alternative-medicine-treatments - CAM- for-cancerbeyond-the-basics. Accessed 06 November 2015.

11. Black LI, Clarke TC, Barnes PM. Use of Complementary Health Approaches among Children Aged 4-17 years in the Unites States: National Health Interview Survey 2007-2012. National Health Statistics Report. 2015;10(78):1.

12. $\mathrm{NIH}$. Mind-Body Medicine Practices in Complementary and Alternative Medicine. National Centre for Complementary and Alternative Medicine. 2010.

13. Hwang J, Kim W, Ahmed M, et al. The use of complementary and alternative medicine by Korean breast cancer women: Is associated with severity of symptoms?. Compl and Altern Med. 2015.

14. Mitha S, Nagarajan V, Babar MG, et al. Reasons of using complementary and alternative medicines (CAM) among elderly Malaysians of Kuala Lumpur and Selangor states: An exploratory study. J Young Pharm. 2013;5(2):50-3.

15. Perveen N, Khan NH, Sarriff A. A study on herbal drug utilization in health care students. J Young Pharm. 2013;5:50-3.

16. Ministry of Health Republic Indonesia. Peraturan Menteri Kesehatan Republik Indonesia Nomor 1109/Menkes/Per/IX/2007 tentang Penyelenggaraan Pengobatan Komplementer-Alternatif di Fasilitas Pelayanan Kesehatan. Depkes RI. 2007.

17. Saibul N, Shariff Z, Rahmat A, et al. Use of complementary and alternative medicine among breast cancer survivors. Asian Pacific $J$ of Cancer Prev. 2012;13(8):4081-6

18. Cassileth B, Lusk E, Guerry D, et al. Survival and quality of life among patients receiving unproven as compared with conventional cancer therapy. The New England J of Med. 1991;324(17):180-5.

19. Tautz E, Momm F, Hasenburg A, Guethlin C. Use of complementary and alternative medicine in breast cancer patients and their experiences: A crosssectional study. Euro J of Cancer. 2012;48(17):3133-9.

20. Kucukoner M, Bilge Z, Isikdogan A, et al. Complementary and alternative medicine usage in cancer patients in southeast of Turkey. Afr J Tradit Compl Altern Med. 2013;10(1):21-5

21. Ernst $\mathrm{E}$. The Role of complementary and alternative medicine. British Med J. 2000;321(7269):1133-5

22. Swisher, EM, Cohn DE, Goff BA, et al. Use of complementary and alternative medicine among women with gynecologic cancers. Gynecologic Oncology. 2002;84(3):363-7.

23. Gulluoglu BM, Cingi A, Cakir T, Barlas A. Patients in northwestern Turkey prefer herbs as complementary medicine after breast cancer diagnosis. Breast Care. 2008;3(4):269-73

24. Algier LA, Hanoglu Z, Özden G, Kara F. The use of complementary and alternative medicine in cancer patients in Turkey. European $\mathrm{Jl}$ of Onc Nursing. 2005;9:138-46.

25. Teng $L$, Jin $K$, He K, et al. Use of complementary and alternative medicine by cancer patients at Zhuci Hospital, China. African J of Trad. Compl and Altern Med. 2010;7:322-30.

26. Lee MM, Lin SS, Wrensch MR, et al. Alternative therapies used by women with breast cancer in four ethnic populations. J of the Nation Cancer Inst. 2000;92(1):42-7.

27. Peteet JR, Balboni MJ. Spirituality and Religion in Oncology. Cancer J for Clinicians. 2013;63(4):280-9.

28. Levine EG, Aviv C, Yoo G, et al. The benefits of prayer on mood and well-being of breast cancer survivors. Support Care Cancer. 2009;17(3):295-306.

29. Bokmand $\mathrm{S}$, Flyger $\mathrm{H}$. Acupunture relieves menopausal discomfort in breast prospective, double blinded, randomized study. The Breast. 2012;22(3):320-3.

30. Wang L, Bao T. Acupuncture for Cancer Patients: Practice and Research. Intech Open Access Publisher. 2013.

31. Wanchai MS, Armer JM, Stewart BR. Complementary and alternative medicine use among women with breast cancer: A systematic review. Clin J of onc nursing. 2010:14-4:E45

32. Moschen R, Kemmler G, Schweigkofler H, et al. Use of alternative/complementary therapy in breast cancer patients: A psychological perspective. Support Care Cancer. 2001;9(4):267-74.

33. Diaz LA, Torregrosa L, Benítez, L, et al. Plant-based complementary and alternative medicine used by breast cancer patients at the Hospital Universitario San Ignacio in Bogotá, Colombia. Universitas Scientiarum. 2012;17(3):291-302.

34. Boon $\mathrm{H}$, Olatunde F, Zick S. Trends in complementary/alternative medicine use by breast cancer survivors: Comparing survey data from 1998 and 2005. BMC Women's Health. 2007:7(1):4

35. Albright NS. A review of some herbal and related products commonly used in cancer patients. J of the American Dietetic Association. 1997:97(10):S208-15. 